\title{
The Determination of Oxytocin Levels in Posterior Pituitary and Plasma of Rats by a Radioimmunoassay
}

\author{
Shigeru AONUMA and Yasuhiro KOHAMA \\ Faculty of Pharmaceutical Sciences, Osaka University, Osaka, Japan
}

The method of a radioimmunoassay for oxytocin was developed. Antibody was produced in rabbits by the repeated injections of oxytocin-bovine serum albumin conjugate emulsified with Freund complete adjuvant, and ${ }^{131} \mathrm{I}$-oxytocin was prepared by the modified chloramine $\mathrm{T}$ method and purified with two successive gel filtrations through the column of Sephadex G-15. The radioimmunoassay was carried out by incubation of a mixture of antibody, ${ }^{131} \mathrm{I}$-oxytocin and oxytocin sample for 2 days at $4{ }^{\circ} \mathrm{C}$, using saline- $0.01 \mathrm{M}$ phosphate buffer ( $\mathrm{pH} 7.4$ ) containing $0.25 \%$ egg albumin as a diluent buffer, followed by separation of antibody-bound hormone (B) from free (F) by the dextran coated charcoal method (or ammonium sulfate precipitation method). The radioactivity of $\mathrm{F}$ (or B) and total reaction mixture was estimated, and the contents of oxytocin were calculated from the percentage of B. The sensitivity was $10 \mu \mu \mathrm{g}(4 \mu \mathrm{U})$. Crude oxytocin extracted from the posterior pituitary of cow according to Kamm's method equally cross-reacted to synthetic oxytocin used as a standard in this assay, without any interferences from any substances except oxytocin that was included in this extract. But the cross reactivity of synthetic lys-vasopressin to oxytocin was only $0.5 \%$, and bovine serum albumin employed in the process of antibody production did not show any influences on the assay of oxytocin.

This radioimmunoassay method was applied for the determination of oxytocin contents in biological samples of rats. Pituitary samples were prepared by extracting with $0.25 \%$ acetic acid and by washing with ether. Plasma samples were prepared by extracting with cold acetone and $0.25 \%$ acetic acid, and by washing with ether. The reproductibility of oxytocin from plasma by this extraction method was 63\%. The normal levels of oxytocin were ca $1.4 \mu \mathrm{g} / \mathrm{mg}$ in the posterior pituitary and ca $40 \mu \mu \mathrm{g} / \mathrm{ml}$ in plasma, but not detectable in the anterior pituitary of rats. The oxytocin levels decreased to ca 1.1 $\mu \mathrm{g} / \mathrm{mg}$ in the posterior pituitary and to ca $30 \mu \mu \mathrm{g} / \mathrm{ml}$ in plasma 2 weeks after male and female rats were castrated. By this assay method it was confirmed that the plasma oxytocin levels during a reproductive cycle of female rats increase just before and after parturition and 1 minuite after suckling. In the determination of rat biological samples a result of bioassay by a rat uterine muscle contractian method was about $10 \%$ higher than this radioimmunoassay.

(See pp. 1008 1017) 
1008

\title{
Oxytocin の Radioimmunoassay によるラット後葉, 血漿中 Oxytocin の測定
}

\author{
大阪大学薬学部
}

青 沼 繁, 小 浜 靖 弘

（昭和46年12月 3 日受付）

\begin{abstract}
oxytocin の鋭敏な定量法として radioimmunoassay を試みた。抗体は oxytocin-BSA 結合物を用い， B と F の分離は dextran coated charcoal 法及び塩析法を使用した. 感度は $10 \mu \mu \mathrm{g}$, vasopressin との 交叉反応性は約 $0.5 \%$ であつた。本法によりラット後葉及び血漿中 oxytocin の測定が可能で, 雌雄ラッ 卜において去势後それらの oxytocin 合量が減少するてと及び雌性ラット血漿 oxytocin が分婏直前及 び直後, 哺乳直後に著明に増加するととが認められた。
\end{abstract}

従来より oxytocin の検定法として用いられている生物学的方法は一般に操作か煩雑で, 類似のペプタイ ドや acetylcholine などにも反応性を示すなど特異性に欠け, また内在性の oxytocin を検定する場合にも 予め複雑な抽出精製操作が必要という難点がある．近年多くの蛋白質及びペプタイドにおいて免疫学的特異 性を利用した radioimmunoassay が開発され，血中の微量ホルモンの定量に利用でさるなど鋭敏なホルモ

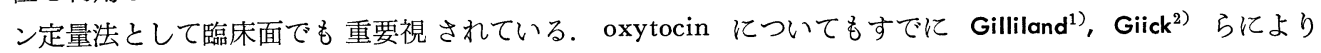
radioimmunoassay が報告されているが， oxytocin が低分子ペプタイドで，非常に不安定であるため抗体 の作成や ${ }^{131} \mathrm{I}$ による標識操作などに困難さを併ない，内在性の oxytocin を定量できるまでには至つてい ない，そこで本報では oxytocin の鋭敏な radioimmunoassay を確立する目的で oyxtocin-牛血清アルブミ ン結合物を抗原として用いるととにより抗体を作成し， chloramine $\mathrm{T}$ を用いて調製した ${ }^{131} \mathrm{I}$-oxyticin を 用い oxytocin の定量化について検討を加光た。 その結果 dextran coated charcoal 法あるいは塩析法によ る radioimmunoassay により oxytocin を定量でき，さらにラット後葉及び血墏中の oxytocin の測定に この方法を適用し充分実用出来るととを認めたので報告する.

\section{実 験 方 法}

\section{試料の調製}

標準 Oxytocin：合成 oxytocin を使用した。 oxytocin は英局第11版記戴のラット子宮収縮効力 400I.U./ $\mathrm{mg}$ を有し,ブタノール：酰酸：水（4:1:5)による一次元上昇法ペーパークロマトグラフィーにかけ た後等分割した沪紙片からの溶出液の Folin 試薬による呈色反応及び子宮収縮効力の試験においてともに 一致する Rf 值 0.35 の単一スポットを与えた.

Vasopressin : 合成 lysine vasopressin (Sigma 社製) はラット血圧上昇法で効力 20I.U./ml を有する ものを用いた。

牛後葉抽出物: 牛下垂体後葉アセトン乾燥末から $\mathrm{Kamm}$ 法 ${ }^{3)}$ 亿準し $0.25 \%$ 酢酸抽出, 硫安分画後酢酸・ I 一テル処理により得られた粉末で, 25I.U./mg のラット子宮収縮効力を有する.

ラットからの試料：体重 150 200g の正常雌雄ラットを撲殺後直ちに後葉及び前葉 を剔出し，それぞれ 1,000 倍量の $0.25 \%$ 酶酸でホモジナイズ後, $100^{\circ} \mathrm{C}, 5$ 分間加熱抽出し, 遠心分離した上清をエーテルで洗い 測定試料とした．血漿試料については体重 150〜200g の正常雌雄ラット心臓から終濃度が $1 \mathrm{mg} / \mathrm{dl}$ となるよ うにへパリンを加えた注射筒を用いて採血し，直ちに低温にて遠心分離して血漿を分離した。血漿に 9 倍量 
の冷アセトンを加えよく攪伴した後遠心分離し，上清を減圧乾固し，残査にもとの血漿の $1 / 2$ 量の $0.25 \%$ 酢 酸を加え $100^{\circ} \mathrm{C} ， 5$ 分間加熱抽出後遠心分離した上清をエーテルで洗い， $1 \mathrm{~N} \mathrm{NaOH} \mathrm{で} \mathrm{pH}$ を中性付近に もどし測定試料とした。

生理的状態の変化に伴なう生体中 oxytocin の変動を調べるため去勢後 2 週間目の雌雄ラットの後葉及び 血漿, また倠ラットの生殖過程中すなわち交尾前 12 時間以内，妊娠 10 日目，分婏前 6 時間以内，分婏後 1 時 間以内及び哺乳後 1 分以内に採血して得た血漿をそれぞれ上記の如く調製して測定試料とした.

Oxytocin-牛血清アルブミン (BSA) 結合物 : Shick ${ }^{4}$ らの方法に従つて BSA $20 \mathrm{mg}$ を含む 0.1M phosphate buffer ( $\mathrm{pH}$ 7.5) $5 \mathrm{ml}$ に toluene-2, 4-diisocyanate $0.1 \mathrm{ml}$ を加え, 25 分間, $0^{\circ} \mathrm{C}$ ではげしく㩭伴後 遠心分離した上清 $2 \mathrm{ml}$ をり，乙の溶液に oxytocin 約 $5 \mathrm{mg}$ を含む $0.1 \mathrm{M}$ borate buffer ( $\mathrm{pH} 9.5) 2 \mathrm{ml}$ を加え，90分間 $37^{\circ} \mathrm{C}$ で incubation した。 反応液を $0.1 \mathrm{M}\left(\mathrm{NH}_{4}\right)_{2} \mathrm{CO}_{3}$ に対して 4 時間，さらに $0.9 \%$ $\mathrm{NaCl}-0.01 \mathrm{M}$ phosphate buffer（pH 7.4）（以下 PBS と略す）に対して20時間透析を行ない結合物を得た。

\section{抗血清の作成}

Oxytocin または牛後葉抽出物に対する抗血清 : oxytocin $250 \mu \mathrm{g}$ (100I.U.) または牛後葉抽出物 $4 \mathrm{mg}$ (100I.U.) を生理食塩水 $1 \mathrm{ml}$ 飞溶解後等量の Freund complete adjuvant に懸濁させ, 体重 $2 \mathrm{~kg}$ 前後の 正常雄性家鬼の皮下，筋肉内及び foot pad に注射した. さらに 1 週 1 回づつ 3 回同様な免疫を行ない, 最初の注射から 5 週間目に耳静脈より採血後血清を分離し， $-20^{\circ} \mathrm{C}$ 亿保存し，使用に供した.

Oxytocin-BSA 結合物に対する抗血清: oxytocin-BSA 結合物溶液 $0.8 \mathrm{ml}$ (oxytocin 400I.U. に相当) に等量の Freund complete adjuvant を加えて懸濁させたものを家鬼の皮下, 筋肉内及び foot pad に注 射した。ささらに 3 週及び 6 週間目に同様な抗原注射液 を皮下及び筋肉内に注射， 9 週間目に $250 \mu \mathrm{g}(100$ I.U.) の oxytocin を adjuvant 法により皮下及び筋肉内に注射した． 5 週間目及び10週目に採血し血清を 分離した. 10 週目の血清について $56^{\circ} \mathrm{C}, 30$ 分間加温して非働化し, 血清 $1 \mathrm{ml}$ 当り $160 \mu \mathrm{g} の \mathrm{BSA}$ 及び0.25 mlの正常ラット血清で吸収した後硫安分画法 ${ }^{5}$ により 品として得た. 対照として BSA に対する抗血清を作成した。すなおち BSA を 1 回 $2 \mathrm{mg}$ の割合で adjuvant 法により家鬼を 1 週 1 回づつ 4 週間免疫し， 5 週目に血清を得た. BSA 抗血清は BSA に対する沈降 反応において oxytocin-BSA 抗血清とほほ同等の力価を示した. BSA 抗血清からも oxytocin-BSA 抗血清 の場合と同様にして $ケ$ ーグロブリンを分画した．また対照として正常家鬼からも血清を得た．

\section{抗血清によるラット子宮収縮効力の中和試験}

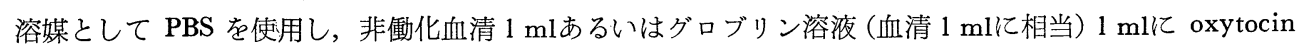
$100 \mathrm{mU} / 1 \mathrm{ml}$ を加え, $4{ }^{\circ} \mathrm{C}, 24$ 時間 incubation した. 反応後 3,000 rpm で15分間遠心分離した上清につい て英局第11版記戴のラット子宮收縮試験法に準じ残存効力を検定した。

\section{抗血清中の L-Cystine Aminopeptidase 活性の測定}

和田法 ${ }^{6)}$ 亿準じ無処置血清あるいは非働化血清 $0.2 \mathrm{ml}$ 亿基質 L-cystine- $\beta$-dinaphthylamide $0.5 \mathrm{ml}$ を加え, $37^{\circ} \mathrm{C}$ または $4{ }^{\circ} \mathrm{C} に て 30$ 分間反応させた。 TGA により除蛋白し, 沪過後沪液 $2 \mathrm{ml} 4 \mathrm{~g} / \mathrm{ml} の$ p-dimethylaminobenzealdehyde 液 $2 \mathrm{ml}$ を混合し，30分後分光光度計で $450 \mathrm{~m} \mu$ の波長の吸光度を測定した。標準とし $て \beta$-naphthylamine を用い，単位は血清 $100 \mathrm{ml}$ が 1 時間に基質から $1 \mathrm{mg} の \beta$-naphthylamine を分解す る活性を 1 単位 $(\mathrm{mg} / \mathrm{d} \mathrm{l} / \mathrm{hr})$ とした.

\section{${ }^{131}$ I-Oxytocin の調製}

chloramine $\mathrm{T}$ 法 $^{7)}$ 亿従い日本アイソトープ協会から購入した $\mathrm{Na}^{131} \mathrm{I} 2 \mathrm{mC}$ を含むバイアル中に $0.5 \mathrm{M}$ phosphate buffer ( $\mathrm{pH} 7.5$ ) $0.025 \mathrm{ml}$, chloramine T $50 \mu \mathrm{g} / 0.025 \mathrm{ml}$ を加光, さらに oxytocin $1.5 \mu \mathrm{g} / 0.01 \mathrm{ml}$ を加えて 1 分間よく混合した後 sodium metabisulfite $100 \mu \mathrm{g} / 0.05 \mathrm{ml}$ 次いで $2.5 \mathrm{mg}$ 卵アルブミン（以下 EA と略す）を含む $0.25 \%$ 酶酸 $0.7 \mathrm{ml}$ を直ちに加え反応を止めた．ての反応液をあらかじめ $20 \mathrm{mg} の \mathrm{EA} て ゙$ 前処 置した Sephadex G-15 のカラム $(1 \times 15 \mathrm{~cm})$ により0.25\%酩酸を用いて溶出し, ${ }^{131} \mathrm{I}$-oxytocin を分離した。 ${ }^{131}$ I-oxytocin はブタノール：酶酸 水 $(4: 1 ： 5)$ の溶媒系による一次元上昇法ペーパークロマトグラフ 
ィー及び抗体との結合性から確認し，さらに Sephadex G-15 のカラムで再クロマトグラフィーを行なつて 精製し， $0.25 \%$ EA を含む $0.25 \%$ 酰酸溶液として $4{ }^{\circ} \mathrm{C}$ 亿て保存した。 なお調製した ${ }^{131} \mathrm{I}$-oxytocin は再ク ロマトグラフィー後 1 週間以内に使用した.

\section{Radioimmunoassay の方法}

抗原，抗体及び試料などの希翻ては全て $0.25 \% \mathrm{EA}$ を含むPBS を用いた。

抗原抗体結合物 (B) と遊離の抗原 $(\mathbf{F})$ の分離 : dextran coated charcoal 法 ${ }^{8)}$ (DCG 法と略す) と硫 安による塩析法を使用した．DCG は 0.25\% EA を含むPBS で調製した $5 \%$ charcoal と $0.5 \%$ dextran （平均分子量約 $77,000 ）$ を等量混合したものを原液とし，50倍希瀵した溶液 $1 \mathrm{ml}$ を抗原抗体反応液に加え混 合した後10分間放置し，遠心分離した上清 $\mathrm{B}$ と charcoal に吸着して沈殿した $\mathrm{F}$ とを分離した.

塩析法は反応液に牛血清 $\gamma$ ーグロブリン $1 \mathrm{mg} / 0.1 \mathrm{ml}, 5.5 \mathrm{M}$ 硫安 $1 \mathrm{ml}$ を加えて 30 分間放置後遠心分離した 上清 $\mathrm{F}$ と沈殿 $\mathrm{B}$ を分離した。両法ともあらかじめ反応液全体の放射能を well type scintillation counter で測定してわき， B と F を分離後沈殿物の放射能を測定し， B\% $(\mathrm{B} /(\mathrm{B}+\mathrm{F}) \times 100)$ を算出した.

標準曲線及び試料の測定 : 希釈した抗血清 $0.2 \mathrm{ml},{ }^{131} \mathrm{I}$-oxytocin $0.2 \mathrm{ml}$ 及び oxytocin 試料 $0.2 \mathrm{ml}$ 在混合 し，さらに $0.4 \mathrm{ml} 0.25 \% \mathrm{EA}$ を含む $\mathrm{PBS}$ を加光 $4{ }^{\circ} \mathrm{C}$ 抗血清 $0.2 \mathrm{ml},{ }^{131} \mathrm{I}$-oxytocin $0.2 \mathrm{ml}$, 陚料 $0.5 \mathrm{ml}$ 及び $1 \% \mathrm{EA}$ を含む PBS $0.1 \mathrm{ml}$ を混合して incubation した. 反応後 DCG 法により B と F を分離して B \%を算出後 oxytocin の標準曲線より測定值を読みとつ た. 測定值は 3 例以上の平均值として求め, 標準曲線は試料測定の度に作成した.

\section{実 験 結 果}

\section{抗血清による Oxytocin のラット子宮収縮効力の中和試験}

Table I そおいて 2) 〜 5) は免疫開始後 5 週間目に得られた血清であるが， oxytocin 単独，牛後葉抽 出物，oxytocin-BSA 結合物に対する抗血清によりそれぞれ oxytocin の効力が中和されるととが認められ た. しかし oxytocin 単独による免疫では中和効力は弱く, oxytocin 以外の物質が抗原中に共存する場合 の方が oxytocin に対する抗体が容易に産生された。 そこで radioimmunoassay に使用する抗血清として

Table I. Inhibition of biological activity of oxytocin by antiserum

\begin{tabular}{l|c}
\hline \multicolumn{1}{c|}{ Serum } & $\begin{array}{c}\text { Inhibitory activity* } \\
\text { (mU./ml) }\end{array}$ \\
\hline \hline 1) Normal & $4.0 \pm 1.3$ \\
2) Anti oxytocin & $6.8 \pm 0.6$ \\
3) Anti posterior pituitary extract & $15.8 \pm 1.0$ \\
4) Anti oxytocin-BSA (5 weeks)** & $26.0 \pm 3.0$ \\
5) Anti BSA & $2.5 \pm 1.0$ \\
6) Anti oxytocin-BSA (10 weeks)** & $204.0 \pm 30.1$ \\
7) 6) after absorbed with BSA and rat serum & $192.0 \pm 21.2$ \\
8) $\gamma$-Globulin from 1ml of 6) undiluted & $70.9 \pm 2.3$ \\
9) $\beta$-Globulin from 1ml of 6) undiluted & $15.3 \pm 0.8$ \\
10) $\gamma$-Globulin from lml of 5) & $2.8 \pm 0.1$ \\
\hline
\end{tabular}

*The mixture of $1 \mathrm{ml}$ of serum or globulin solution and $100 \mathrm{mU} . / 1 \mathrm{ml}$ of oxytocin in PBS ( $\mathrm{pH} 7.4$ ) was iucubated for 24 hours at $4^{\circ} \mathrm{C}$, followed to an assay on rat uterine muscle in vitro. In 4) and 6), serum diluted to $1 / 4$ was used. Result was shown as the mean value of 3 experiments \pm S.E. of inhibitory activity per $\mathrm{ml}$ of serum undiluted.

**4) was obtained 5 weeks and 6) was obtained 10 weeks after the first immunization. 
Table II. L-Cystine aminopeptidase (CAP) activity in anti oxytocin serum

\begin{tabular}{l|c|c|c}
\hline \multicolumn{1}{c|}{ Serum } & $\begin{array}{c}\text { Incubation } \\
\text { temperature } \\
\left({ }^{\circ} \mathrm{C}\right)\end{array}$ & Non treated & $\begin{array}{c}\text { CAP activity }(\mathrm{mg} / \mathrm{dl} / \mathrm{hr})^{*} \\
\left(56^{\circ} \mathrm{C}, 30 \mathrm{~min}\right)\end{array}$ \\
\hline \hline Normal & 37 & 4.65 & 1.38 \\
& 4 & 0.83 & 0.13 \\
Anti oxytocin & 37 & 4.73 & 1.13 \\
Anti posterior & 4 & 0.98 & 0.12 \\
pituitary extract & 37 & 5.04 & 2.25 \\
Anti oxytocin-BSA & 4 & 0.95 & 0.30 \\
(10weeks) & 37 & 4.96 & 0.95 \\
\hline
\end{tabular}

*CAP activity was determined by Wada's method using L-cystine- $\beta$-dinaphthylamide as a substrate and $\beta$-naphthylamine as a standard.

Fig. 1. Separation of ${ }^{131} \mathrm{I}$-oxytocin on SephadexG-15 column $(1 \times 15 \mathrm{~cm})$ using $0.25 \%$ acetic acid. The column was presaturated by $0.25 \%$ acetic acid containing $20 \mathrm{mg}$ of egg albumin before a sample applied.

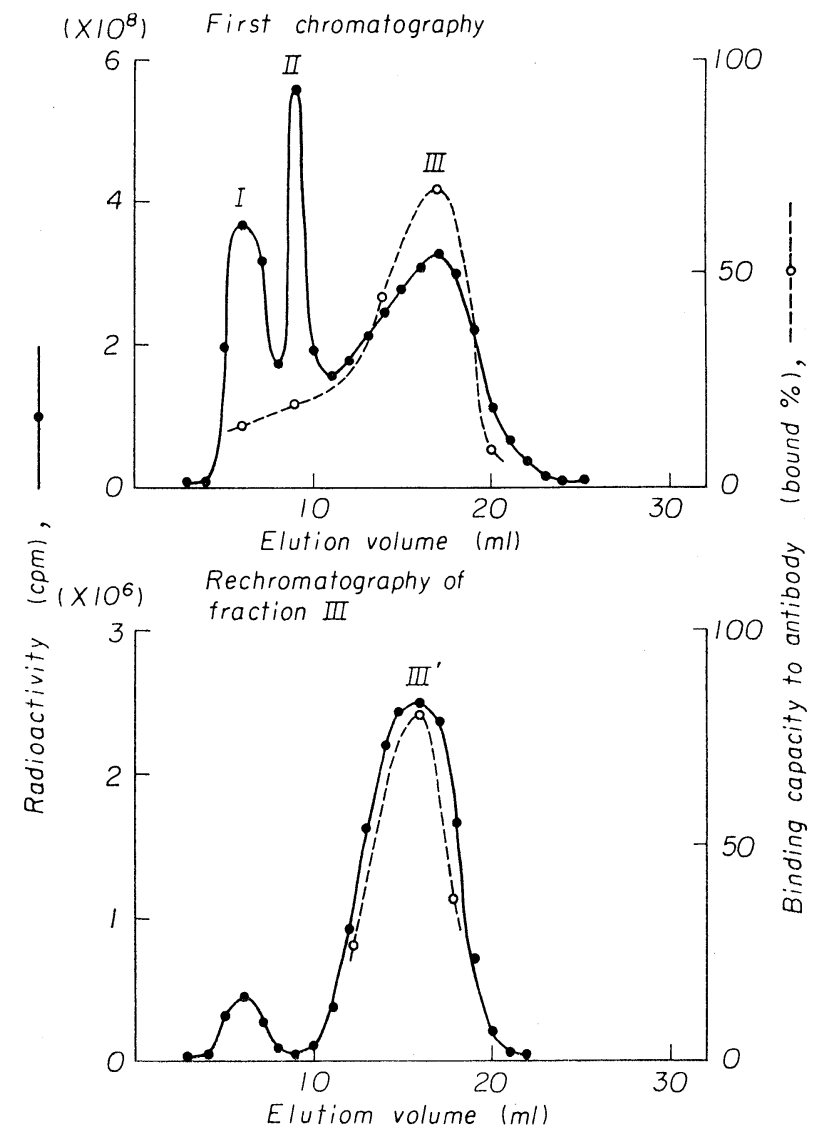


最も中和効力の強い oxytocin-BSA 免度家鬼を選び, さ引に追加免疫して10週目に抗血清を得た。 ての抗 血清の中和効力は $\mathrm{ml}$ 当り $204 \mathrm{mU}$. と強く, BSA 及びラット血清で吸収した後も効力の減少は見られ なかつた. しかし抗血清から分画された リンでは中和効力が約 $1 / 3$ 亿減少し， $\beta$-グロブリ ン分画にも多少抗体の分散が認められた。従つて radioimmunoassay には oxytocin-BSA 抗血清を

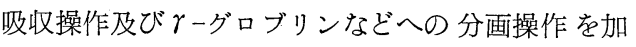
えずそのまま使用した。

\section{抗血清中の L-Cystine Aminopeptidase 活性}

抗血清作成の際大量の oxytocin 投与により家鬼 血中 oxytocin 分解酵素活性が増加する可能性が考 えられるので本活性と平行する L-cystine aminopeptidase 活性を各抗血清につき測定した. その結果 Table II に示す如くいずれの抗血清の活性も正常 血清と同程度であつた。 そして血清を非働化した後 $4{ }^{\circ} \mathrm{C}$ で反応を行なつた場合には本活性は無視できる

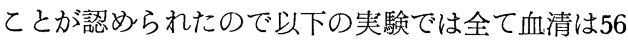

${ }^{\circ} \mathrm{C}, 30$ 分間加温して非働化後 $4{ }^{\circ} \mathrm{C}$ て使用した.

\section{${ }^{131}$ I-Oxytocin $の$ 精製}

chloramine T 法により標識された ${ }^{131}$ I-oxytocin

の Sephadex G-15 のカラムにおける溶出曲線は
Fig. 2. Paper radiochromatogram of each fraction in Fig. 1 on Toyo filter paper No. 51 using the soluent of butanol $:$ acetic acid : water $(4: 1: 5)$ in ascending method.
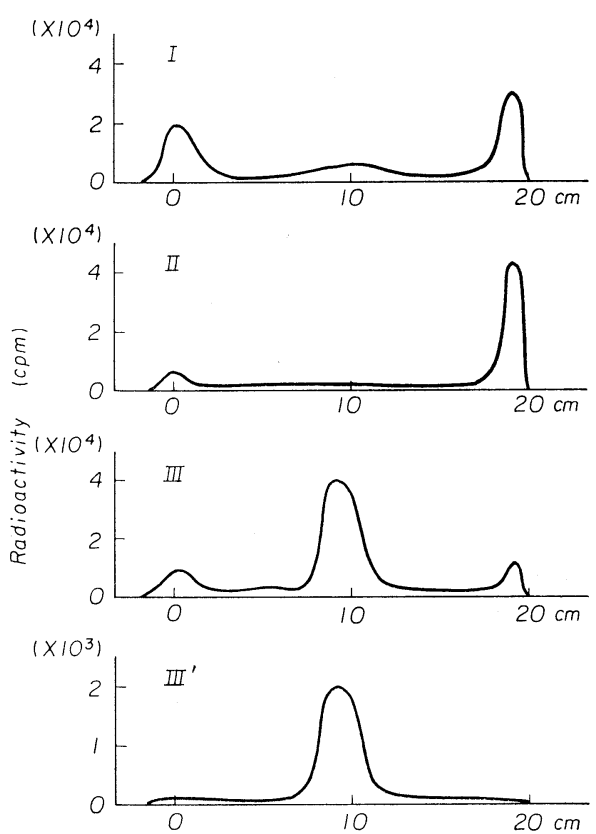

Fig. 1 亿示す如くであつた. 各フラクションのペー パークロマトグラフィー (Fig. 2) 及び抗体との結合性 (Fig. 1) から ${ }^{131}$ I-oxytocin は最後のフラクション IIIに溶出されてくるてとが涊められた。 フラクションIには EA に吸着した ${ }^{131} \mathrm{I}$-oxytocin の分解物，無機 ${ }^{131}$ Iが，IIには無機 ${ }^{131} I$ が溶出された． IIIには ${ }^{131} I$-oxytocin の他に少量の無機131Iなどが含まれていたので Sephadex G-15 のカラムで再に 精製を行なつたところ Fig. 1, 2 に示すようにペーパークロマトグラム上 単一 (Rf: 0.5) で，抗体との結合性の高い ${ }^{131}$ I-oxytocin が得られた。比放射能は Greenwood ${ }^{7)}$ らの方法 により概算したとてろ約 $400 \mu \mathrm{Ci} / \mu \mathrm{g}$ であつた。 なお Greenwood ら ${ }^{7)}$ の原報通りヨウ素化反応後還元剤を 添加し, ゲル沪過を行なつた場合にはヨウ素化 oxytocin の抗体結合能力及び子宮収縮活性は完全に消失し たが，本実験の如く還元剤を加えた後直ちに EA を含む $0.25 \%$ 酢酸を添加し反応液を希哷するてとにより 抗体との結合能力は約 $80 \%$ ，生物活性は約50\%残存するてとを認めている. また ${ }^{131} \mathrm{I}$-oxytocin の精製法と して Sephadex G-109)，G-252) 及び Amberlite IRA-4001) の使用はいずれも不適当であつた.

\section{Radioimmunoassay に関する基礎的検討}

$\mathrm{B}$ と $\mathrm{F}$ の分離： DCC 法及び塩析法による $\mathrm{B}$ と $\mathrm{F}$ の分離を Fig. 3 示した. $\mathrm{B}$ と $\mathrm{F}$ を分離するための $\mathrm{DCC}$ の最適濃度は50倍希釈であり，乙の濃度における DCG 法と塩析法の $\mathrm{B}$ 及び $\mathrm{F} の$ 分離能はほぼ同程度であ つた. 以下の実験には操作の簡単な DGC 法を用いて B と Fの分離を行なつた。

抗血清の ${ }^{131}$ I-oxytocin 結合能: $30 \mu \mu \mathrm{g}$ の ${ }^{131} \mathrm{I}$-oxytocin 亿倍数希釈した抗血清を加え， $4{ }^{\circ} \mathrm{C}, 2$ 日間 incubation した後 B\%を求めたとてろ Fig. 4 亿示すように200倍希釈の抗血清は約80\%の ${ }^{131}$ I-oxytocin を 結合する能力を有し，6400倍希釈においても約20\%の結合能を示した．実際の測定には50\%前後の結合能を 示す1000から3000倍希釈の抗血清を使用した。

反応時間 : Fig. 5 亿示す如く 2 日間の incubation で反応はほぼ平衝に達つし， 7 日目まで B \%の值はほ 
Fig. 3. Separation of oxytocin bound to antibody from free.

In a) $1 \mathrm{ml}$ of various diluted DGG solutions or in b) $1 \mathrm{mg} / 0.1 \mathrm{ml}$ of bovine serum $\gamma$-globulin and $1 \mathrm{ml}$ of $5.5 \mathrm{M}$ ammonium sulfate were used for $1 \mathrm{ml}$ of reaction mixture. ( $\bigcirc)$ antiserum, $(x)$ normal serum, antiserum minus normal serum

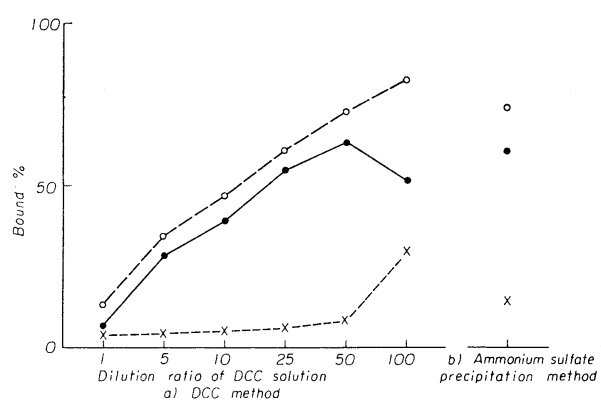

Fig. 5. Effect of incubation time on binding of ${ }^{133}$ I-oxytocin to antibody. Thirty $\mu \mu \mathrm{g}$ of ${ }^{131} \mathrm{I}$-oxyt1cin was incubated at $4^{\circ} \mathrm{C}$ with antiserum diluted to $1 / 3000$.

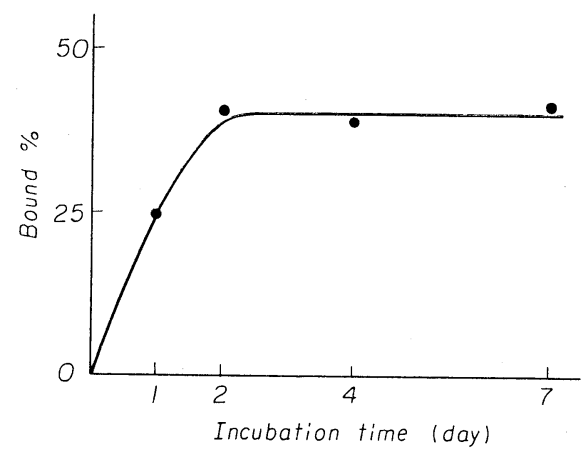

とんど変化しないてとが認められたので反応時間は 2 日間とした。

\section{標準曲線}

以上の如く基礎的条件について検討した上で
Fig. 4. Titration curue of anti oxytocin-BSA serum.

Serial dilutions of antiserum were incubated for 2 days at $4^{\circ} \mathrm{C}$ with 30 $\mu \mu \mathrm{g}$ of ${ }^{131} \mathrm{I}$-oxytocin. Binding capacity was measured by DCC method.

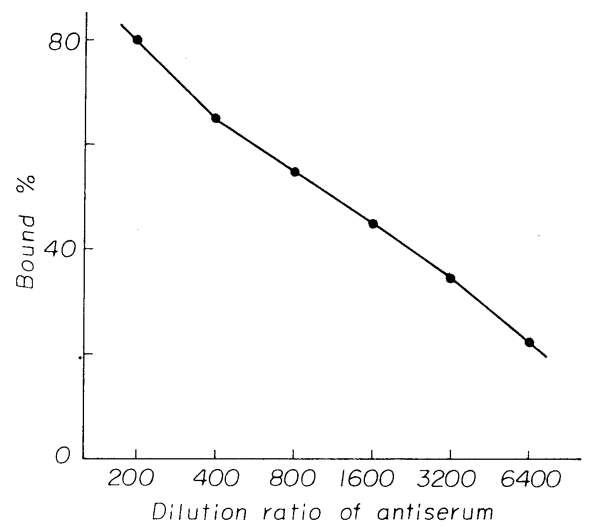

Fig. 6. Standard curve for oxytocin radioimmunoassay. The mixture of $30 \mu \mu \mathrm{g}$ of ${ }^{131}$ I-oxytocin and antiserum diluted to $1 / 3000$ was incubated with various concentrations of standard oxytocin for 2 days at $4{ }^{\circ} \mathrm{C}$. Bound $\%$ was determined by DGG method.

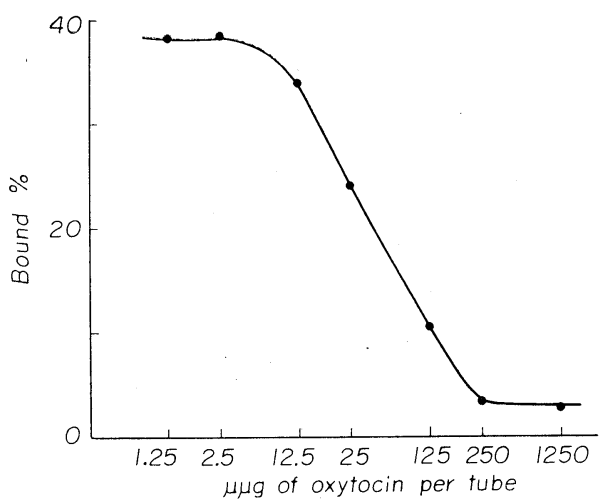

oxytocin の radioimmunoassay の標準曲線を作成した．その結果 Fig. 6 亿示すように $30 \mu \mu \mathrm{g}$ の ${ }^{131} \mathrm{I}$-oxy-

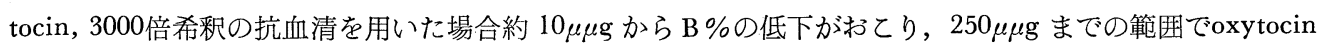
を定量するととができた。 また $100 \mu \mu \mathrm{g}$ の ${ }^{131}$-oxytocin と1000倍希秎の抗血清を用いると Fig. 7 の如く測 定範囲は約 $25 \mu \mu \mathrm{g}$ から $25 \mathrm{~m} \mu \mathrm{g}$ の間であつた. なお標準曲線は incubation 期間が $2 \sim 7$ 日目の間では Fig. 7 亿示すように変化せず，本法の条件下では incubation 中に oxytocin の分解などによる免疫学的活 性への影響は認められなかつた。 以上の如く本 radioimmunoassay により最高検出感度 $10 \mu \mu \mathrm{g}(4 \mu \mathrm{U}$.$) で$ oxytocin を定量的に测定できることが認められた. 
Fig. 7. Effect of incubation time on standard curve.

One hundred $\mu \mu \mathrm{g}$ of ${ }^{131} \mathrm{I}$-oxytocin and antiserum diluted to $1 / 1000$ were used. ( $x$ ) 1 day, (O) 2 days, $(\triangle)$ 4 days, (O) 7 days

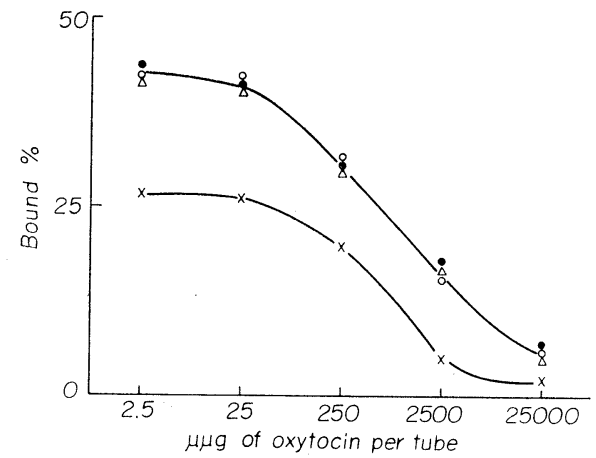

Fig. 8. Cross reaction of posterior pituitary extract, sythetic lys-vasopressin and BSA in oxytocin radioimmunoassay. (O) oxytocin, $(O)$ posterior pituitary extract, $(\triangle)$ vasopressin, $(\square)$ BSA

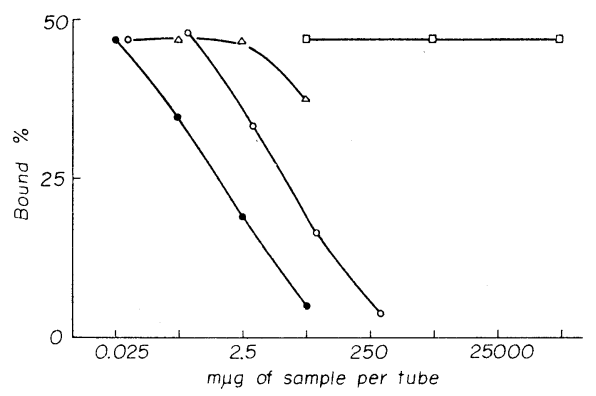

\section{Radioimmunoassay $の$ 特異性}

本法の特異性を調べるため牛後葉抽出物，合成 lysine vasopressin 及び抗体作成の際 oxytocin の結合 蛋白として使用した BSA そついて測定を行なつた. その結果 Fig. 8 から明らかなように 25I.U./mg の子 宮収縮効力を示す牛後葉抽出物は oxytocin と交叉反応を示し，子宮収縮効力に対する免疫学的活性に換算 すると oxytocin と全く同じ活性を示した. すなわち牛後葉抽出物中に含まれる vasopressin などのペプタ イドや oxytocin 以外の物質に影響されることなく後葉中の oxytocin のみが特異的に測定された. 一方 vasopressin は oxytocin の約0.5\%しか交叉反応性を示さず（vasopressin は 400I.U./mg の血圧上昇作用 を有すると仮定した），本法における vasopressin の交叉反応は無視するととが出来た．また BSA も250 $\mu \mathrm{g}$ までの量では交叉反応を示さず抗体として oxytocin-BSA 抗血清を用いた本法が BSA に妨害されるこ となく oxytocin を特異的に測定できることが認められた.

\section{ラット生体内試料の測定}

正常ラット後葉及び血獎中 Oxytocin : 後葉より $0.25 \%$ 酢酸抽出, 血漿よりアセトン抽出した抽出物中の oxytocin が本 radioimmunoassay により測定でき, 結果を Table III に示した. 後葉抽出物を子宮収縮 試験により検定したとてろ雄ラットでは $1.56 \pm 0.32 \mu \mathrm{g} / \mathrm{mg}(0.70 \sim 2.82 \mu \mathrm{g} / \mathrm{mg})$, 雌ラットでは $1.67 \pm 0.41 \mu \mathrm{g} /$ $\mathrm{mg}(0.57 \sim 3.80 \mu \mathrm{g} / \mathrm{mg})$ であり, radioimmunoassay の結果と同様各ラット間の個体差は大きいが, radioi-

Table III. Determination of oxytocin levels in posterior pituitary and plasma of normal and castrated rats by radioimmunoassay

\begin{tabular}{|c|c|c|c|}
\hline \multirow{2}{*}{\multicolumn{2}{|c|}{ Group }} & \multicolumn{2}{|c|}{ Oxytocin level* } \\
\hline & & $\begin{array}{c}\text { Posterior pituitary } \\
(\mu \mathrm{g} / \mathrm{mg})\end{array}$ & $\begin{array}{c}\text { Plasma } \\
(\mu \mu \mathrm{g} / \mathrm{ml}) \\
\end{array}$ \\
\hline \multirow{2}{*}{ Male } & Normal & $1.37 \pm 0.45 \quad(0.56 \sim 3.00)$ & $35.1 \pm 10.6(<15.7 \sim 53.0)$ \\
\hline & Gastrated & $1.09 \pm 0.46 \quad(0.13 \sim 2.86)$ & $27.2 \pm 11.8(<15.7 \sim 57.6)$ \\
\hline \multirow{2}{*}{ Female } & Normal (esterus) & $1.49 \pm 0.38 \quad(0.16 \sim 4.15)$ & $49.0 \pm 9.0(<15.7 \sim 70.8)$ \\
\hline & Castrated & $1.13 \pm 0.30 \quad(0.58 \sim 2.25)$ & $36.2 \pm 5.3(\quad 15.7 \sim 56.2)$ \\
\hline
\end{tabular}

*Mean value of 3 to 5 rats, in which oxytocin could be detected, \pm S.E.

(range from minimum value to maximum.) 
mmunoassay の結果の方が少し小さな值を与えた。 なお前葉抽出物においても子宮収縮法で $0.57 \pm 0.10 \mu \mathrm{g} /$ $\mathrm{mg}(0 \sim 0.70 \mu \mathrm{g} / \mathrm{mg})$ の活性を示したのにもかかわらず radioimmunoassay では使用した 5 匹のラットに おいていずれも oxytocin を検出するてとはできなかつた．また血漿についても血漿に既知量の oxytocin 加えアセトン抽出による oxytocin の回収率を測定したととろ radioimmunoassay では約63\%, 子宮収縮 法では約74\%であり, 後葉, 前葉及び血漿においていずれも子宮収縮試験法による結果の方が radioimmunoassay の值よりも高いととが認められた. Table III に示した血漿中 oxytocin 含量は回収率 $63 \%$ に より補正したものであるが，後葉の場合と同様各個 体間の差は大きく，各群 5 匹中の0〜2匹において本 法では oxytocin を検出するてとが出来なかつたが, 平均值において雌ラットの oxytocin 含量か雄より も高い傾向を示した．なお血墏試料測定の際血漿そ のままあるいは TCA 抽出 ${ }^{13)} し た$ 後測定する方法 はいずれも oxytocin の回収率が $10 \%$ 以下であり本 法の測定試料として適当ではなかつた.

去勢ラット後葉及び血獎中 Oxytocin：去勢後 2 週間目の後葉中 oxytocin 含量は雌雄 ラットとも Table III に示すとおり正常ラットに比較して減少 する傾向を示した．血墏中 oxytocin も後葉の場合 と同様去勢により減少することが認められた。

雌性ラット生殖期間中の血獎中 Oxytocin : 交尾, 妊娠, 分婏及び哺乳期間中のラット血漿 oxytocin

Fig. 9. Plasma oxytocin levels during reproductive cycle in rat.

Rat was bled from heart; a), within 12 hours before mating; b), within 6 hours before parturition ; c), within 1 hour after paturition and d) within 1 minuite after suckling. *Minimum sensitivity

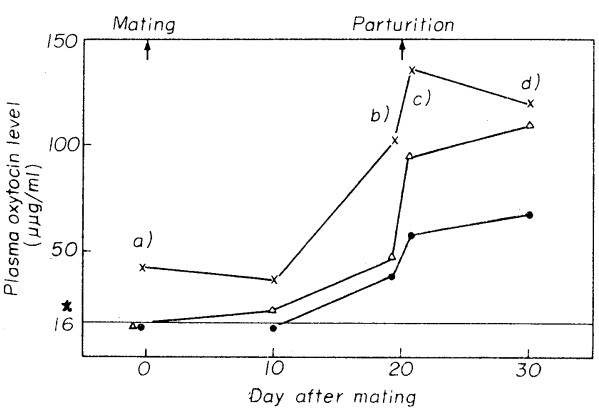
はFig. 9 にみられるように 3 例とも交尾, 妊娠中期までは正常值を保つているが, 分娩直前に増加し, 分婏 直後ではさらに著るしく増加することが認められた。 また哺乳期においても高濃度の oxytocin が放出され ていることが認められた。

\section{考察}

分子量数干以下の抗原性が極めて弱い angiotensin $\mathrm{II}^{10)}$, bradykinin ${ }^{10)}$, vasopressin ${ }^{11)}$ など低分子物質 の抗体を作成する場合，一般に免度抗原として高分子蛋白などとの結合物を用いる方法がとられている.

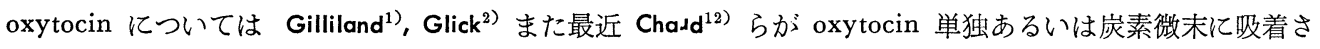
せたものを免疫に使用しているが，6〜10ケ月というかなり長い免疫期間を要している. 著者らは oxytocin の免度抗原として oxytocin 単独, 牛後葉抽出物及び oxytocin-BSA 結合物について比較検討し, oxytocin 単独よりは oxytocin 以外の物質が共存する方が抗体の産生は容易であり， oxytocin-BSA を用いるととに より約 3 ケ月で3000倍希釈で使用できる抗血清を得ることができた。ささら BSA で吸収後も中和効力が娍 少しないとと及び oxytocin の抗原抗体反応系に BSA が影響しないととから oxytocin についても結合蛋 白を使用する方が簡単な抗体作成法であると言える.

oxytocin の如き低分孔ペプタイドの抗原抗体反応を行なう場合血清中のペプチダーゼに注意せねばなら ない，そてで抗血清から抗体 $\gamma$ ーグロブリンの分画を試みたが，抗体活性が約 $1 / 3$ に減少し， $\beta$-グロブリン 分画へも活性が分散するととが認められ適当ではなかつた。一方 angiotensin II などにおいて angiotensinase を除くため $\mathrm{EDTA}^{13)}$, dimercaprol ${ }^{14)}$, edetic acid ${ }^{14)}$ などの添加が試みられているが, 本実験に用い た抗血清中の CAP 活性は正常の場合と変らず，非働化後 $4{ }^{\circ} \mathrm{C}$ て反応を行なえば CAP 活性はほとんと

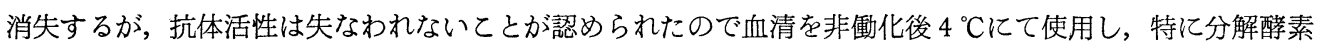
阻害剤などの添加は行なわなかつた．著者らはすでに oxytocin の長期間投与による各種藏器及び体液中の 
oxytocin 不活性化醳素の変動について検討し, 子宮を除いて他の藏器及び体液中の 醉素活性は影響を受け ないととを認めており ${ }^{15)}$ ，今回の結果と一致している.

ICI 法による oxytocin のヨウ素化についてはすでに報告したが淿), 調製の簡便さと比放射能の点で radioimmunoassay には chloramine $\mathrm{T}$ 法が適当であつた. chloramine $\mathrm{T}$ 法において特に還元剤 sodium metabisulfite は oxytocin の生物学的及び免疫学的活性を阻害するため， $0.25 \%$ 䣷酸による希勫と保護剤 としての EA の添加は必須であり，EA の添加はヨウ素化反応物を Sephadex G-15 で溶出する際損傷を 受けた ${ }^{131}$ I-oxytocin などが EA とともに溶出されるという利点があつた。 得られた ${ }^{131}$ I-oxytocin はぺー パークロマトグラフィーの Rf 值 ${ }^{16)}$ から oxytocin 1 分子当り 2 個の I 原子が導入されたものが主成分であ ると思われる．さらに ${ }^{131}$ I-oxytocin は抗体と約80\%の結合能を有し，本 radioimmunoassay に充分使用す るととができた。

oxytocin の抗原抗体反応物の分離法としてすで飞二抗体法 ${ }^{2}$, 塩析法 ${ }^{17)}$, 透析法 ${ }^{18)}$, 電気泳動法 ${ }^{1)}$ などが 試みられているが，本実験で検討した DGG 法もほぼ塩析法と同じ分離能を示すてとが認められた．最近 Chard らも DCG 法について同様な結果を報告している ${ }^{12)}$. DCG 法は低分子物質には有効な方法で, oxytocin おいても他の方法に比較して操作が簡便, 安価, 短時間内に結果が得られるてと及び多数の試料 の測定に適しているなど多数の利点が認められた。

本法の検出感度は $10 \mu \mu \mathrm{g}(4 \mu \mathrm{U}$.$) であり，種々の希釈段階の抗血清及び { }^{131} \mathrm{I}$-oxytocin を使用するととに より比較的広い範囲において oxytocin の定量ができた．本法による牛後葉抽出物の測定結果から天然の oxytocin も合成品と全く同様な活性を示し，oxytocin と類似した vasopressin などとの反応性はほとんぞ 無視するてとができ，oxytocin のみを特異的に測定するてとができた。

実用化の手がかりとして radioimmunoassay によりラット生体試料を測定し，oxytocin の主要な生理作 用の 1 つである子宮収縮作用を利用した生物学的検定法による值と比較検討した結果，下垂体からの $0.25 \%$ 酷酸抽出物, 血漿からのアセトン抽出物では生物学的検定法による值の方が約 $10 \%$ 高く出た. てれは試料中 に oxytocin 以外に子宮収縮作用物質が含まれているためと考えられる．本法にわいて血漿をそのまま測定 すると oxytocin は検出されなかつたが，血墏そのままでは血漿中の何らかの物質が免疫反応を阻害するか， $\mathrm{B}$ と $\mathrm{F}$ の分離の際に高濃度の蛋白などによる防害があると考えられるが詳細は不明であつた．アセトン抽出

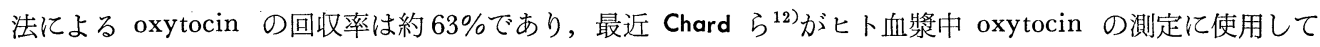
いる fuller's earth 吸着法と同程度であつた。

血墏中 oxytocin 值についてはすでに生物学的検定法により牛，羊，ヤギ，ヒト及びラットにおいて正常

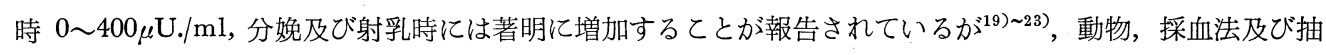
出法などによりかなり異なつた值が出されている．本法で測定したラット血漿中 oxytocin 值はラット間の 個体差は大きいが平均約 $16 \mu \mathrm{U} . / \mathrm{ml}$ であり，使用した20匹のラットの内 6 匹について oxytocin を検出する ことが出来なかつたととから血漿中 oxytocin 值はかなり低いと推定される.

一方種々の生理的状態のラット後葉及び血漿中 oxytocin を測定した結果，去勢により雌雄とも後葉及び 血漿中の濃度が低下し，oxytocin の分泌あるいは代謝が性ホルモンにより影響されているてとが認められ， また妊娠後期，分婏，哺乳期間中には著明に血槳中 oxytocin が増加しており，著者らの尿中子宮収縮物質

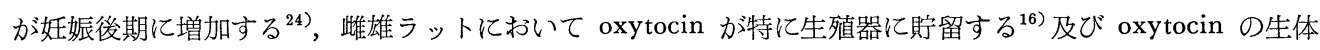
内にわける不活性化が特に卵巣に上り強く影響される ${ }^{15)}$ といら報告と考光併わせると妊娠, 分娩, 乳汁のみ ならず雄性動物における生殖現象にも oxyrocin が影響を及ぼしているてとが推察される。

現在 oxytocin の生理学的意義についてはまだ不明な点が多く, radioimmunoassay は血中 oxytocin の 簡便な測定法として oxytocin の動的代謝のみならず分泌及び作用機序などの生理化学的研究並びに臨床検 查への応用面において果す役割は大きいものである. 


\section{結}

論

oxytocin-BSA 結合物に対する抗体と chloramine T 法で調製した ${ }^{131} I$-oxytocin を用い DCG 法また は塩析法による radioimmunoassay により $10 \mu \mu \mathrm{g}(4 \mu \mathrm{U}$.$) の oxytocin, 及びラット後葉, 血墏からそれぞ$ れ0.25\%酶酸抽出，アセトン抽出された oxytocin を定量するてとができた。測定值はラット子宮収縮法に よる值より約 $10 \%$ 低く, lysine varopressin との交叉反応性は約 $0.5 \%$ であつた.

本 radioimmunoassay により雌雄ラット後葉及び血漿中の oxytocin が去勢後減少するととを認めた. また分婏前後及び哺乳期に血漿中 oxytocin が著明に増加するてとが免疫学的方法により認められた。

終りに本研究の試料の一部を提供された帝国臟器製薬株式会社に感謝するとともに実験の一部を担当され た岡上伊都子修士, 瀬古はるみ学士に心から感謝する。

本論文の要旨は次の 2 つの学会に扔いて発表した。「日本薬学会第89年会, 名古屋, 1969 年 4 月」「第 19 回日本薬学会近畿支部総会, 大阪, 1969年10月」

\section{文献}

1) P.F. Gilliland and T.E. Prout : Metabolism, $14: 918$ (1965).

A. Kagan and P. Kumaresan : Advan. Exp. Med. Biol., 2 : 93 (1968).

2) S.M. Glick, M. Wheeler, Aldlich, I.W. Rowe and E.P. Bugbee : J. Am. Chem. Soc., 50 : 573 (1928).

3) O. Kamm, T.B. and S.J. Singer : J. Biol. Chem., $236: 2477$ (1961).

5）中村 弘, 尾上 薰: 蛋白質, 核酸, 醉 素, $11: 1587$ (1966). 6) 和田 等: 日産, $18: 1077$ (1966).

7) F.G. Greenwaod, W.M. Hunter and J.S. Grover : Biochem. J., 89 : 114 (1963).

Gottlieb and S.J. Bleicher : J. Clin. Endocr., $25: 1375$ (1965).

8) V. Hervert, K.S. Law, G.W. Garson : Obstet. Gynec., 29 : 862 (1967).

10) T.L. Goodfriend, L. Levine and G.D. Fasmann : Science, $144: 1344$ (1964).

11) M.A. Permutt, G.W. Parker and R.D. Utiger : Endocrinology, $78: 809$ (1966).

12) T. Chard, M.J. Kitau and J. Landon : J. Endocr., $46: 269$ (1970).

13) F.M. Dietrich : Immunochemistry, $4: 65$ (1967). 14) G.W. Boyd, J. Landon and W.S. Peart : Lancet, $2: 1002$ (1967). $\quad 15 ）$ 青沼 繁, 田中慶一, 谷口伊都 子, 山元 弘: 日内分泌誌, $46: 789$ (1970). 16）青沼 繁, 田中慶一, 赤松弘子：日内分泌誌, $46: 387$ (1970). 17) T. Chard, M.L. Forsling and M.J. Kitau : J. Endocr., $43: 1$ xi (1969). 18) M. Wheeler, A. Kagan and S.M. Glick : Clin. Res., $14: 479$ (1966). 19) T. Chard, N.R.H. Boyd, M.L. Forsling, A.S. McNeilly and J. Landon : J. Endocr., $48: 223$ (1970). 20) J.A. Coch, G. Fielitz, J. Brovetto, H.M. Cabot, H. Coda and A. Faga : J. Endocr., $40: 137$ (1968). 21) J.S. Robert and L. Share : Endocrinology, $84: 1076$ (1969). $\quad 22)$ 浜野 穆: 横浜医学, 19 : 90 (1968). 23) R. Caldeyro-Barcia and H. Heller : Oxytocin, (1961), 358-377, 412-424, 425436, Pergmon Press, Oxford. 24）青沼 繁, 浜 一技, 誉田裕子, 住田幸子: 薬学研究, $34: 11$ (1962). 